\title{
HEALTH AND ECONOMIC HAZARDS OF MICROBIOLOGICAL CONTAMINATION OF BROILER POULTRY RATIONS AND INGREDIENTS WITH SPECIAL INTEREST TO SOME TOXIGENIC FUNGI
}

\author{
A.A. Abdel Rhaman* ; H.K. Shoeib* ; M.M. Ahmed** \& A.M. Abdel Fattah* \\ *Agr. Research Center - Animal Health Institute- Dokki, giza, Egypt. \\ **Dept. Of Animal Hygiene-Faculty of Vet. Medicine, Assiut University, Egypt.
}

\begin{abstract}
:
Out of 100 samples of commercial broiler poultry rations and ingredients were collected from poultry processing plants in different localities at El-Minia and Assiut Governorates and examined for their microbiological contamination. The obtained results showed variable incidence percentages of fungal isolates that included Aspergillus spp. $(46.46 \%)$ in the form of A. Flavus (25.20\%), A. parasiticus (14.17\%) and A. niger (7.09\%); Penicillum spp. $(22.05 \%)$ in the form of $P$. rubrum $(7.07 \%), P$. citrinum $(10.24 \%)$ and $P$. expansum $(4.72 \%)$; Fusarium spp. $(18.11 \%)$ in the form of F. tricintum (12.60\%) and F. nivale (5.51\%); Mucor spp. $(7.87 \%)$ and Yeast spp. $(6.30 \%)$. The mean counts of total aerobic viable bacteria ranged from $(1.80 \pm 0.27) 10^{2}$ to $(6.48 \pm 2.19) 10^{4} \mathrm{CFU} / \mathrm{g}$ at $37^{\circ} \mathrm{C}$ and mean of total coliforms counts with a minimum of $(2.26 \pm 0.31) 10$ and a maximum mean of $(7.31 \pm 2.45) 10^{3} / \mathrm{g}$. The mean counts of typical E. coli varied from zero to $(2.82 \pm 1.38) 10^{2} / \mathrm{g}$., while the mean values of feacal streptococci counts ranged from zero to $(27.63 \pm 3.76) / 100 \mathrm{~g}$. and also $\mathrm{Cl}$. perfringens mean counts ranged from zero to $(6.41 \pm 2.57) 10^{2} / \mathrm{g}$. The most of important pathogenic and potentially pathogenic bacterial isolates were, Staphylococcus spp. (14.12\%); E. coli $(3.92 \%) ; \mathrm{Cl}$. perfringens $(5.10 \%)$, Pseudomonas. aeroginosa (5.88\%) and other enteric organisms with variable percentages. Proteolytic and lipolytic activities of the important fungal isolates were done to prove their ability to produce mycotoxins in the poultry rations and their ingredients. In the feeding experiment, two groups of total 40 poultry chicks were used, each group contained 20 of one day old chicks that were directly fed for 6 weeks on the examined rations that revealed mould and enzymatic activities in case of the first group, while the second group received the same rations but after their supplementation with the antitoxic agent (Antitoxin liver protector Bedgen 40 Premix), that was added by the ratio of $1 \mathrm{~g} / \mathrm{kg}$. ration and was fed for the same time as in group one. Blood samples from the chicks were analyzed for liver function (SGOT\&SGPT), Ca, P, and plasma proteins. The alteration of these serological parameters were estimated. Marked decrease in the mean body weight gain of broiler chicks of group 1 was observed. The total feed consumption of chicks was also calculated. The differences of the tested parameters between the two chicken groups were detected and evaluated. The hygienic and protective measures that improve the keeping quality of poultry rations and their ingredients were discussed for insurance and safeguard of poultry and human health.
\end{abstract}




\section{INTRODUCTION :}

The world now has been well acquainted with fungal contamination of feeds and their hazards to human and animals. Microbiological quality of poultry feeds have been a comparatively unexplored area of poultry science, but the developments over the past decade or so have slowly focused attention to this area, these developments, have been the establishment of poultry feeds in the way of the recognition of mycotoxins as a widespread economic threat to profitable poultry husbandry.

Recently special attention to provide information on the incidence and activities of fungi in mixed feeds. However poultry feeds have not received special mycological attention in spite of the fact that they prepared basically from cereals and concentrate mixtures, where fungi are the most important contaminants (El-Kady, et. al., 1982; Chang-Yen, et. al., 1992 and Abaraca, et. al., 1994). Many species of several genera of fungi were isolated from cereals used for human food and are the main components of animal and poultry rations among which Aspergillus species occurred in a wide range as a contaminant (Youssef, et. al., 1985; Hussain, et. al., 1993 Abdel- Fattah, 1994). Aspergillus species were most frequently encountered in cereals. Penicillium species were also isolated, however Fusarium, Mucor, Rhizpous and Alternaria were the least contaminant moulds (AbdelKader, et.al., 1979; El-Kady, et. al., 1982; ElMaraghy, 1984 and Gathumbi, et. al., 1996) and all cereals are liable to be contaminated by fungi which their majority are toxigenic.

The production of a low nutritive value food as the result of fungal growth include one of the several drawbacks of the presence of moulds in the feed ingredients (Bartove, et.al., 1982). Marked decrease in the protein and fat contents of mouldy grains was obviously reported (Ogundero, 1987).

The other factor which is of great importance is that grains or other formed rations contaminated by fungi could be a source of their by-products of which mycotoxins are very dangerous. Contamination of grains by biologically active substances that arising as the result of metabolic process of fungal contamination has been existed (Abdel-Fattah, 1994 and Prabaharan, et. al., 1999). Mycological studies of poultry feeds and ingredients are of significant importance for determining the distribution of mycotoxin- producing fungi as their toxic metabolites have been detected in many food stuffs. Though mycocontamination of poultry feeds represents a considerable percentage of the overall contamination problems, where the toxins arising from Aspergillus, Fusarium, and Penicillium spp. seriously affect poultry health and production (Robert \& Mora, 1978; Pier, 1992 and Hussein, et. al., 1993).

Marked decrease in the body weight of breeding and broiler chicks fed on fungal and toxin contaminated rations. This is accompanied by alteration of the serological parameters (as liver enzymes, protein, fat, Ca \& P). Otherwise, P.M. changes involving mainly liver, kidney and spleen were observed (Malkinson, et. al., 1982; Niemice, et. al., 1989; Fernandez, et.el., 1994 and Prabaharan, et. al., 1999). Unquantifiable economic impact of the fungal toxins on animal feeds is the subtle chornic effect of the toxin in subclinical small doses. This includes loss in feed efficiency or poor feed conversion 
rates which are generally manifested as reduced growth rates and lack of weight gains (Hegazy, et.al., 1991).

Recently, Prabaharan, et. al. (1999) revealed a decreased in the total feed consumption of birds that fed on diet treated with aflatoxin when compared with the control one. Conflicting results with Balachandran \& Ramarkrishnan, 1988 and Giambrone, et. al., 1985, who found a significant effect only on feed conversion but not on feed intake in broilers due to aflatoxicosis.

Unproper storage and transport of rations and ingredients could offer an optimum conditions of temperature and humidity that enable the contaminated fungi to grow and produce their metabolites (Bartove, 1983).

Bacteriological evaluation of poultry feeds as well as ingredients takes a part in several researches where a wide variety of pathogenic and potentially pathogenic organisms were isolated among which Salmonella and other enteric organisms were occurred and to some extent anaerobes and Staphylococci were encountered (Tabib, et. al., 1981; Cox, et. al., 1983 and Ahmed, et. al., 1995). Mixed feeds and their basic raw plant materials are considered unexplored area of poultry science. They represent a main source of disease spread so they must receive proper bacteriological attention... Enterobacter agglomerans, E. clocae and Klebsiella pneumonae were the most frequently encountered Enterobacteriaceae group, but there was no correlation between the level of Enterobacteriaceae and the presence of Salmonella in the poultry feeds (Cox, et. al.,1983).
The problem of microbial contamination and mycotoxicosis in poultry husbandry tell now is very important causing severe economic losses in this industry as well as public health hazard. The cause of this problem is branched and confused so many researches have been enhanced and from this situation, the present investigation was designed to throw light on the microbiological contamination of some poultry rations and ingredients that obtained from some poultry processing units at El-Minia and Assiut Governorates and to evaluate and monitoring the probable effect of such contamination on health and the performance of poultry chickens.

\section{MATERIALS AND METHODES :}

\section{1-Collection of samples:}

One hundred samples of broiler poultry rations and their ingredients were collected from poultry processing plants in different localities at El-Minia and Assiut Governorates, represented by 20 commercial broiler rations, 10 yellow corn meals, 10 concentrated mixtures, 10 soya bean meals, 10 fish meals, 10 meat meals, 10 bone meals, 10 lime stone, 5 lysine and 5 methaionine samples. The samples were collected separately in sterile plastic bags and transported to the laboratory for microbiological examination with a minimum of delay.

\section{2- Mycological examination:}

The mycological isolation was carried out using sterile technique by inoculated $1 \mathrm{gm}$ of each sample into a sterile tube containing 9 ml. saline solution from which, $1 \mathrm{ml}$. was transferred into each sterile petridish and mixed with $15 \mathrm{ml}$. of $45^{\circ} \mathrm{C}$ molted media (Sabauroud dextrose agar and Modified 
Czapek Dox medium). The culture media were incubated at $25^{\circ} \mathrm{C}$ till fungal growth was observed(7-10 days). The growing fungi were identified based on their morphological cultures and microscopic characteristics (Cruickshank, et. al., 1980). The isolated strains of Aspergillus, Fusarium and Pencillium were tested for their proteolytic and lipolytic activities using skim milk and gelatin liquefaction tests according to ElGendy (1966); Uliman \& Blasin (1974) and Das, et. al. (1979).

\section{3- Bacteriological examination:}

Preparation of the samples for bacteriological examination: Fifty grams of each sample were placed in a sterile flask with $\mathbf{4 5 0}$ $\mathrm{ml}$ of a sterile physiological saline and were vigorously shaken for $1 \mathrm{~min}$. to make 1:10 basal dilutions. Ten fold serial dilutions were made till $10^{-7}$ according to Cox,et. al., 1983).

Aerobic viable plate count:- The colony forming units (CFU) were carried out according to A.P.H.A. (1985) by using standard plate count agar (Oxoid).

Total coliforms count: The total Coliforms were counted in pour plates of violet red bile agar with $1 \%$ glucose (Baily \& Scott,1994). Typical Escherichia coli was counted according to (Quinn, et. al., 1994). Enumeration of Enterococci was performed by MPN technique as described by Elmer et. al. (1994). Enumeration of $\mathrm{Cl}$. Perfringens was carried out according to Toply \& Wilson (1990).

The identification of the isolated organisms of Staphylococcus spp; Enterobacteriaceae groups; other enteric pathogens and Clostridium perfringens were done biochemically according to Cruickhank, et. al. (1980).

\section{4- Feeding experiment :}

Effect of mycotic contamination of poultry feeds on the performance of broiler chicks was studied. Total 40 Lohmann breed chicks of one day old were divided into two groups each of 20 chicks. The first group of chicks were directly fed on the started commercial rations which previously detected to be mycologically contaminated with fungi that having enzymatic activities . While the rations of the second group of chicks were supplemented with antitoxic agent (antitoxin liver protector Bedgen 40 premix), added and mixed by the ratio of $1 \mathrm{~g} / \mathrm{gk}$ ration. Chicks of the two groups were reared for 6 weeks where their water and feeds were given ad libitum. Both of the two groups were observed for morbidity and mortality rates daily, as well as, for their end weight body gain and feed efficiency. Five chicks from each group were scarified at $\mathbf{4 2}$ days old and blood samples were collocated and the serum obtained was analyzed for total protein, albumin, globulin, Ca, $P$ and liver enzymes (GOT and GPT), according to Weichsalbaum (1946) and Drupt (1974), using test kits (BioMerieux , Bains / France ).

\section{5- Statistical analysis of results :}

Data for the performance response variables were statistically analyzed by Sendercor and Cochran (1980). 


\section{RESULTS :}

The obtained results are tabulated in tables (1-8).

Table (1) : Incidence percentages of pathogenic and potentially pathogenic fungi isolates of 100 examined commercial broiler rations and their ingredients.

\begin{tabular}{|c|c|c|c|c|c|c|c|c|c|c|c|c|c|}
\hline \multirow[t]{2}{*}{$\begin{array}{r}\text { Rations \& } \\
\text { Ingredients }\end{array}$} & \multirow[t]{2}{*}{$\begin{array}{c}\text { No. of ex. } \\
\text { samples }\end{array}$} & \multirow[t]{2}{*}{$\begin{array}{c}\text { No of +ve } \\
\text { samples }\end{array}$} & \multirow[t]{2}{*}{$\begin{array}{c}\text { No. of } \\
\text { isolates }\end{array}$} & \multicolumn{2}{|c|}{$\begin{array}{c}\text { Aspergillus } \\
\text { spp. }\end{array}$} & \multicolumn{2}{|c|}{$\begin{array}{c}\text { Fusarium } \\
\text { spp. }\end{array}$} & \multicolumn{2}{|c|}{$\begin{array}{c}\text { Pencilium } \\
\text { spp }\end{array}$} & \multicolumn{2}{|c|}{$\begin{array}{c}\text { Mucor } \\
\text { spp. }\end{array}$} & \multicolumn{2}{|c|}{ Yeasts } \\
\hline & & & & No & $\%$ & No & $\%$ & No & $\%$ & No & $\%$ & No & $\%$ \\
\hline Br. rations & 20 & 20 & 37 & 19 & 14.96 & 7 & 5.51 & 6 & 4.72 & 3 & 2.36 & 2 & 1.57 \\
\hline Corn meal & 10 & 9 & 22 & 9 & 7.09 & 6 & 4.72 & 5 & 3.94 & 1 & 0.79 & 1 & 0.79 \\
\hline Soya bean & 10 & 7 & 12 & 5 & 3.94 & 2 & 1.57 & 3 & 2.36 & 1 & 0.79 & 2 & 1.57 \\
\hline Fish meal & 10 & 9 & 14 & 5 & 3.94 & 1 & 0.79 & 4 & 3.15 & 3 & 2.36 & 1 & 0.79 \\
\hline Meat meal & 10 & 8 & 4 & 2 & 1.57 & 1 & 0.79 & 0 & $\mathbf{0}$ & 0 & $\mathbf{0}$ & 1 & 0.79 \\
\hline Bone meal & 10 & 6 & 9 & 4 & 3.15 & 2 & 1.57 & 2 & 1.57 & 1 & 0.79 & $\mathbf{0}$ & $\mathbf{0}$ \\
\hline Concentrates & 15 & 12 & 16 & 10 & 7.87 & 2 & 1.57 & 2 & 1.57 & 1 & 0.79 & 1 & 0.79 \\
\hline Golutenine & 5 & 3 & 5 & 1 & 0.79 & 1 & 0.79 & 3 & 2.36 & $\mathbf{0}$ & $\mathbf{0}$ & $\mathbf{0}$ & $\mathbf{0}$ \\
\hline Methionine & 5 & 2 & 4 & 2 & 1.57 & 1 & 0.79 & 1 & 0.79 & $\mathbf{0}$ & $\mathbf{0}$ & $\mathbf{0}$ & $\mathbf{0}$ \\
\hline Lysine & 5 & 3 & 4 & 2 & 1.57 & 0 & 0 & 2 & 1.57 & $\mathbf{0}$ & 0 & $\mathbf{0}$ & 0 \\
\hline Total & 100 & 79 & 127 & 59 & 46.46 & 23 & 18.11 & 28 & 22.05 & 10 & 7.87 & 8 & 6.30 \\
\hline
\end{tabular}

Table (2) : The distribution incidence and frequency percentages of Pathogenic and potentially pathogenic fungi isolated from 100 samples of commercial broiler rations and their ingredients

\begin{tabular}{||l|c|c|c||}
\hline \multicolumn{1}{|c|}{ Fungal isolates } & Total No. of isolates & Total incidence \% & Total frequency \% \\
\hline Aspergillus spp. & 59 & 46.46 & 59 \\
As. flavus & 32 & 25.20 & 32 \\
As.parasiticus & 18 & 14.17 & 18 \\
As. niger & 9 & 7.09 & 9 \\
\hline Penicillium spp. & 28 & 22.05 & 28 \\
P. rubrum & 9 & 7.09 & 9 \\
P. citrinum & 13 & 10.24 & 13 \\
P. expansum & 6 & 4.72 & 23 \\
\hline Fusarium spp. & 23 & 18.11 & 16 \\
F. tricintum & 16 & 12.60 & 7 \\
F.nivale & 7 & 5.51 & 10 \\
\hline Mucor spp. & 10 & 7.87 & 8 \\
\hline Yeast spp. & $\mathbf{6}$ & 6.30 & - \\
\hline Total & 127 & - & \\
\hline
\end{tabular}

Table (3): protease and lipase activity of the isolated fungi from the examined broiler rations and ingredients samples.

\begin{tabular}{||c|c|c|c|c|c||}
\hline \multirow{2}{*}{ Isolated fungi } & \multirow{2}{*}{$\begin{array}{c}\text { No. of tested } \\
\text { isolates }\end{array}$} & \multicolumn{2}{|c|}{ Protease producer } & \multicolumn{2}{c|}{ Lipase producer } \\
\cline { 3 - 6 } & & $\begin{array}{c}\text { No. of +ve } \\
\text { specimens }\end{array}$ & Activity (mm) & $\begin{array}{c}\text { No. of +ve } \\
\text { specimens }\end{array}$ & $\begin{array}{c}\text { Activity } \\
(\mathbf{m m})\end{array}$ \\
\hline Aspregillus spp. & 54 & 45 & $5-20$ & 30 & $8-20$ \\
Fusarium spp. & 21 & 15 & $3-12$ & 10 & $7-18$ \\
Pencillium spp. & 34 & 25 & $6-10$ & 15 & $9-20$ \\
\hline Total & 109 & 85 & - & 55 & - \\
\hline
\end{tabular}


Table (4) : Statistical mean counts of microbial contaminants of 100 commercial broiler rations and their ingredients.

\begin{tabular}{|c|c|c|c|c|c|c|}
\hline $\begin{array}{l}\text { Broiler rations } \\
\text { \& Ingredients }\end{array}$ & $\begin{array}{c}\text { No. of } \\
\text { Samples }\end{array}$ & $\begin{array}{c}\text { Total Viable } \\
\text { Count } \\
\text { \{C.F.U./g at } 37^{\circ} \mathrm{c} \text { \} }\end{array}$ & $\begin{array}{c}\text { Total } \\
\text { Coliform } \\
\text { Count } / g \\
\end{array}$ & $\begin{array}{l}\text { Total E. coli } \\
\text { Count/g }\end{array}$ & $\begin{array}{c}\text { Total } \\
\text { Enterococci } \\
\{\text { MPN/100g } \\
\end{array}$ & $\begin{array}{c}\text { Total Cl. } \\
\text { Perfrigens } \\
\text { Count/g } \\
\end{array}$ \\
\hline Corn meal & 10 & $\left(5.73^{4} \pm 1.33\right) 10$ & $\left(6.13^{3} \pm 1.79\right) 10$ & $(0.20 \pm 2.43) 10$ & $27.63 \pm 3.76$ & 0.0 \\
\hline Soya bean & 10 & $(6.48 \pm 2.19) 10^{4}$ & $(3.93 \pm 0.84) 10^{3}$ & $(2.10 \pm 5.19) 10$ & $19.23 \pm 1.44$ & 0.0 \\
\hline Meat meal & 10 & $(2.18 \pm 1.87) 10^{3}$ & $(2.13 \pm 1.76) 10^{2}$ & 0.0 & 0.0 & $(1.31 \pm 0.17) 10^{2}$ \\
\hline Bone meal & 10 & $(1.80 \pm 0.27) 10^{2}$ & $(2.60 \pm 0.35) 10$ & 0.0 & 0.0 & 0.0 \\
\hline concentrates & 15 & $(2.62 \pm 1.38) 10^{3}$ & $(1.43 \pm 0.42) 10^{2}$ & 0.0 & 0.0 & $(4.74 \pm 0.24) 10$ \\
\hline Gelutonine & 5 & $(3.14 \pm 1.07) 10^{2}$ & $(2.26 \pm 0.31) 10$ & $(1.80 \pm 3.12) 10$ & 0.0 & $(1.43 \pm 0.15) 10$ \\
\hline Total & 100 & & & & & \\
\hline
\end{tabular}

Table (5-a): Incidence percentages of pathogenic and potentially pathogenic microbial isolates of examined commercial broiler rations and their ingredients

\begin{tabular}{||c|c|c|c|c|c|c|c|c|c|c||}
\hline \multirow{2}{*}{ Bacterial isolates } & \multicolumn{2}{|c|}{ Broiler rations } & \multicolumn{2}{|c|}{ Concentrates } & \multicolumn{2}{|c|}{ Golutonine } & \multicolumn{2}{|c|}{ Methionine } & \multicolumn{2}{c|}{ Lysine } \\
\cline { 2 - 9 } & No. & $\%$ & No. & $\%$ & No. & $\%$ & No. & $\%$ & No. & $\%$ \\
\hline Staph. aureus & 3 & 3.95 & 0 & 0.00 & 0 & 0.00 & 0 & 0.00 & 0 & 0.00 \\
Staph. epidermidis & 11 & 14.5 & 1 & 5.88 & 2 & 10.0 & 0 & 0.00 & 1 & 9.10 \\
Micrococci spp. & 13 & 17.1 & 2 & 11.8 & 2 & 10.0 & 1 & 11.1 & 1 & 9.10 \\
Strept. faecalis & 4 & 5.26 & 0 & 0.00 & 0 & 0.00 & 0 & 0.00 & 0 & 0.00 \\
Cl. perfringens & 5 & 6.58 & 2 & 11.8 & 1 & 5.0 & 0 & 0.00 & 0 & 0.00 \\
Ps. aeroginosa & 4 & 5.26 & 2 & 11.8 & 0 & 0.00 & 0 & 0.00 & 0 & 0.00 \\
Alcaligenes faecalis & 5 & 6.58 & 3 & 17.7 & 3 & 15.0 & 1 & 11.1 & 1 & 9.10 \\
Escherchia coli & 3 & 3.95 & 0 & 0.00 & 1 & 5.0 & 0 & 0.00 & 1 & 9.10 \\
Enterobacter cloaca & 7 & 9.21 & 2 & 11.8 & 2 & 10.0 & 0 & 0.00 & 2 & 18.2 \\
Serratia rubidae & 4 & 5.26 & 1 & 5.88 & 2 & 10.0 & 2 & 22.2 & 0 & 0.00 \\
Proteus morganii & 4 & 5.26 & 2 & 11.8 & 1 & 5.0 & 1 & 11.1 & 2 & 18.2 \\
Proteus vulgaris & 5 & 6.58 & 1 & 5.88 & 2 & 10.0 & 2 & 22.2 & 1 & 9.10 \\
Providancia spp. & 1 & 1.31 & 0 & 0.00 & 1 & 5.0 & 1 & 11.1 & 0 & 0.00 \\
Citrobacter freundii & 2 & 2.62 & 0 & 0.00 & 2 & 10.0 & 1 & 11.1 & 1 & 9.10 \\
Citrobacter diversus & 3 & 3.95 & 1 & 5.88 & 1 & 5.0 & 0 & 0.00 & 1 & 9.10 \\
Arizona spp. & 2 & 2.62 & 0 & 0.00 & 0 & 0.00 & 0 & 0.00 & 0 & 0.00 \\
Salmonella spp. & 0 & 0.00 & 0 & 0.00 & 0 & 0.00 & 0 & 0.00 & 0 & 0.00 \\
\hline Total isolates & 76 & & 17 & & 20 & & 9 & & 11 & \\
\hline \hline
\end{tabular}


Table (5-b): Incidence percentages of pathogenic and potentially pathogenic microbial isolates of examined commercial broiler rations and their ingredients

\begin{tabular}{||c|c|c|c|c|c|c|c|c|c|c||}
\hline \multirow{2}{*}{ Bacterial isolates } & \multicolumn{2}{|c|}{ Corn meal } & \multicolumn{2}{|c|}{ Soya meal } & \multicolumn{2}{c|}{ Fish meal } & \multicolumn{2}{c|}{ Meat meal } & \multicolumn{2}{c|}{ Bone meal } \\
\cline { 2 - 10 } & No. & $\%$ & No. & $\%$ & No. & $\%$ & No. & $\%$ & No. & $\%$ \\
\hline Staph. aureus & 1 & 3.45 & 2 & 5.55 & 1 & 4.35 & 0 & 0.00 & 0 & 0.00 \\
Staph. epidermidis & 2 & 6.90 & 4 & 11.1 & 3 & 13.1 & 2 & 9.10 & 3 & 18.75 \\
Micrococci spp. & 3 & 10.3 & 5 & 13.9 & 3 & 13.1 & 2 & 9.10 & 4 & 25.0 \\
Strept. faecalis & 1 & 3.45 & 1 & 2.78 & 0 & 0.00 & 0 & 0.00 & 0 & 0.00 \\
Cl. perfringens & 0 & 0.00 & 0 & 0.00 & 2 & 8.69 & 3 & 13.64 & 0 & 0.00 \\
Ps. aeroginosa & 2 & 6.90 & 2 & 5.55 & 1 & 4.35 & 2 & 9.10 & 2 & 12.5 \\
Alcaligenes faecalis & 3 & 10.3 & 4 & 11.1 & 1 & 4.35 & 1 & 4.54 & 1 & 6.25 \\
Escherchia coli & 2 & 6.90 & 3 & 8.33 & 0 & 0.00 & 0 & 0.00 & 0 & 0.00 \\
Enterobacter cloaca & 3 & 10.3 & 3 & 8.33 & 2 & 8.69 & 2 & 9.10 & 1 & 6.25 \\
Serratia rubidae & 2 & 6.90 & 2 & 5.55 & 1 & 4.35 & 0 & 0.00 & 0 & 0.00 \\
Proteus morganii & 2 & 6.90 & 4 & 11.1 & 1 & 4.35 & 2 & 9.10 & 1 & 6.25 \\
Proteus vulgaris & 2 & 6.90 & 1 & 2.78 & 1 & 4.35 & 3 & 13.64 & 2 & 12.5 \\
Providancia spp. & 1 & 3.45 & 2 & 5.55 & 3 & 13.1 & 1 & 4.54 & 0 & 0.00 \\
Citrobacter freundii & 2 & 6.90 & 1 & 2.78 & 2 & 8.69 & 1 & 4.54 & 1 & 6.25 \\
Citrobacter diversus & 1 & 3.45 & 1 & 2.78 & 1 & 4.35 & 2 & 9.10 & 1 & 6.25 \\
Arizona spp. & 1 & 3.45 & 1 & 2.78 & 1 & 4.35 & 1 & 4.54 & 0 & 0.00 \\
Salmonella spp. & 0 & 0.00 & 0 & 0.00 & 0 & 0.00 & 0 & 0.00 & 0 & 0.00 \\
\hline Total isolates & 29 & & 36 & & 23 & & 22 & & 16 & \\
\hline \hline
\end{tabular}

Table (6): The distribution incidence and frequency percentages of pathogenic and potentially pathogenic bacterial isolates from the total 100 samples of commercial broiler rations and their ingredients.

\begin{tabular}{||l|c|c|c||}
\hline \multicolumn{1}{|c|}{ Types of bacterial isolates } & Total No. of isolates & Total Incidence \% & Total Frequency \% \\
\hline Staphylococcus spp. & 36 & 14.12 & 36 \\
Micrococci spp. & 36 & 14.12 & 36 \\
Streptococcus faecails & 6 & 2.35 & 6 \\
Cl. perfringens & 13 & 5.10 & 13 \\
Ps. aeroginosa & 15 & 5.88 & 15 \\
Alcaligenes faecalis & 23 & 9.02 & 23 \\
Escherchia coli & 10 & 3.92 & 10 \\
Enterobacter cloaca & 24 & 9.41 & 24 \\
Serratia rubidae & 14 & 5.49 & 14 \\
Proteus spp. & 37 & 14.51 & 37 \\
Providancia spp. & 10 & 3.92 & 10 \\
Citrobacter spp. & 25 & 9.80 & 25 \\
Arizona spp. & 6 & 2.35 & 6 \\
Salmonella spp. & 0 & 0.00 & 0.00 \\
\hline \multicolumn{1}{|c|}{ Total } & 255 & - & - \\
\hline
\end{tabular}


Table (7): Statistical mean values of growth performance and feed efficiency parameters of the experimental groups of broiler chickens

\begin{tabular}{||r|c|c||}
\hline \multirow{2}{*}{ Tested parameters } & \multicolumn{2}{|c|}{ Broiler groups } \\
\cline { 2 - 3 } Body weight at 42 days (g/chick) & Group 1 & Group 2 \\
Weight gain (g/chick) & $1586 \pm 23.7$ & $1775 \pm 15.4 * *$ \\
Feed intake (1-42 days, g/chick) & $1550 \pm 16.3$ & $3830 \pm 12.9$ \\
Feed conversion & $3850 \pm 13.8$ & $2.16 \pm 0.053$ \\
Mortality rate & $2.48 \pm 0.74$ & $10 \%$ \\
\hline
\end{tabular}

** Highly significant at $\mathbf{P}<0.01$

Table (8) : Statistical estimated means of total protein, Albumin, calculated Globulin content, GOT, GPT, $C a$ and $P$ in blood serum of the experimental chicken groups

\begin{tabular}{||l|c|c||}
\hline \multicolumn{1}{|c|}{ Tested parameters } & \multicolumn{2}{|c||}{ Broiler groups } \\
\cline { 2 - 3 } Total protein (g/100ml) & Group 1 & Group 2 \\
Albumin (g/100ml) & $3.021 \pm 0.234$ & $3.242 \pm 0.141$ \\
Globulin (g/100ml) & $1.079 \pm 0.085$ & $1.010 \pm 0.100$ \\
GOT (U/L) & $1.942 \pm 0.254$ & $2.232 \pm 0.447$ \\
GPT (U/L) & $93.8 \pm 6.176$ & $91.6 \pm 8.606$ \\
Calcium (mg/d) & $1.6 \pm 0.245$ & $4.6 \pm 0.245^{* *}$ \\
Phosphorus (mg/dl) & $9.488 \pm 1.072$ & $11.078 \pm 0.714$ \\
\hline
\end{tabular}

** Highly significant at $\mathbf{P}<0.01$

\section{DISCUSSION :}

The production of safety food is the hope of governments and the demand of population. The progressive increase of poultry constructions enhances researches to outline the problems of this industry for its economic and public health importance. One of the most important problem is microbiological contamination of the commercial poultry rations and ingredients especially by toxgenic fungi. Moulds have been well known to contaminate cereals, which are the main components of poultry rations and their ingredients. The obtained results of moulds including, Aspregillus; Fausarium; Pencillium; Mucor and Yeast species from the broiler poultry rations and their ingredients were clearly in accordance to (Youssef, et. al.,1985; Hussain et. al.,1993 and Abdel -Fattah, 1994). From the obtained data in (Tables1\&2), it could be concluded that the predominate fungal isolate was Aspergillus spp. $(46.46 \%)$ in the form of Aspergillus flavus (25.20\%); Aspergillus parasticus (14.17\%) and Aspergillus niger (7.09\%). this results were in agreement with the observation of (Abdel-Kader, 1979 and El-kady, et. al.,1982). The total percentages of Penicillium spp., Fusarium spp., Mucor spp. and Yeasts of examined broiler rations and ingredients were $22.05 \%, 18.11 \%, 7.87 \%$ and $6.30 \%$ respectively (Table 2 ). The obtained data were also accorded by the previously mentioned authors as well as, El-Maraghy, 1984; Abdel-Fattah, 1994 and Gathumbi, et. 
al., 1996). From the data illustrated in (Table 1), the broiler rations showed to be highly contaminated followed by corn meal, concentrates and fish meal with total frequency percentages of $37 \%, 22 \%, 16 \%$ and $14 \%$ respectively.

The production of low nutritive quality of poultry feeds as the results of fungal contamination and its growth which was clearly detected by the proteolytic and lipolytic activity of the isolated strains of Aspergillus flavus, Aspergillus parasiticus, Fusarium spp. and Penicillium spp. That were agreed the results of (Bartove, 1983; Adams, 1987 and Abdel-Fatta, 1994). This primary metabolic activity was hardly reflected the ability of these fungi to produce secondary metabolites. The most important of which are the mycotoxins (Aharonwitz \& Cohen, 1981).

The presence of mycotoxins in rations and ingredients as the results of fungal growth was confirmed by several ways. One of which was the biochemical variations of serum used to diagnose the effect of mycotoxins on consumed chicks. Our results in (Table 8) indicated significant changes of some diagnostic serum parameters and there were also distinctive variations of these parameters between the 2 groups of chicks in the present experiment. Marked decrease in serum $C a$ and $P$ concentrations were observed in chicks of group 1 in comparison with those of group 2 where their rations were supplemented with the antitoxic agent (antitoxin liver protector Bedgen 40 premix, added by the ratio of $1 \mathrm{~g} / \mathrm{gk}$ ration). The low serum Ca level is a sensitive indicator of mycotoxication (Fernandez, et al., 1994). Moreover the liver is considered the main target organ in mycotoxicosis of poultry, so alterations in liver enzymes recorded in
(Table 8), were revealed as direct proof of the consumed contaminated rations effects on health status of the group 1 chicks. The mainly affected SGPT (ALT), was markedly decreased in contrast to higher activity of SGOT (AST). While, the changes in the serum plasma proteins were also detected and the variations were clearly demonstrated between the two groups of the chicks. These serum levels were being similar to the observations that were made by (Balachandran \& Ramarkrishnan, 1988 and Fernandez, et. al., 1994). Because of the liver is the main affected organ of mycotoxicosis, mycotoxins produce important changes in hepatic metabolism that affect protein, lipid and enzyme synthesis, which finally pronounced as reduction of the weight of the growing chicks. This was clearly noticed in our investigation (Tables 7 \& 8). Highly significant difference at $\mathbf{P}<0.01$ in body weight of 42 days old chicks was observed in broilers of group 1 when was compared with group 2. The mean body weight gain was lower in group1, which fed on the mycotoxincontaminated rations when compared to group 2 (225 gm), as, illustrated in (Table 7). These findings were in close agreement with the results recorded by Ruff \& Wyatt (1978) ; Singh \& Malhotra (1978); Udaya, et. al. (1995) and Prabaharan, et. al. (1999). Total means of feed consumption of broiler chicks were $3850 \pm 13.8$ and $3830 \pm 12.9 \mathrm{gm} /$ chick for group 1 and group 2 respectively as shown in (Table 7). The total feed consumption revealed a slight decrease in the treated group 2 with the antitoxin. There was no clear reduction in feed intake of broiler chicks conversion. The group1 chicks showed a low mean feed efficiency $(2.48 \pm 0.074)$ in comparison with the mean of $(2.16 \pm 0.053)$ for chicks of the group2, as shown in (Table 7). 
This was in conformity with that reported by Balachandran \& Ramarkrishnan (1988) and Okoye \& Okeke (1986). A major of unquantifiable economic impact on poultry health from consuming rations contained toxins in subclinical small doses, as the subtle chronic effect of the toxin. This includes loss in feed efficiency or poor conversion rates which are generally manifested as reduced growth rates and lack of weight gains as recorded by (Bodine and Mertens, 1983 and Hegazy, et. al., 1991). So the obtained results showed a significant growth rate suppression ,but not feed consumption leading to poor feed efficiency and conversion, as were observed in chicks of group 1 which may be attributed to the mycotoxins effect as was agreed with Bryden,et. al. (1980) and Reddy, et. al. (1984). Poor feed efficiency in group 1 was due to the significant reduction in the body weight gain of broiler chicks without proportional reduction in feed intake. In case of poultry farming, this is severely impacted the cost effectiveness of the operation due to either reduction in the net weight of the finished product or from the increasing amounts of offered broiler feeds that are needed to reach expected marked weight.

Contamination of poultry rations and their ingredients with pathogenic and potentially pathogenic organisms induce serious diseases. Thus, practical and effective methods must be developed and utilized to eliminate them from the feed supply (Cox, et. al.,1983). The total means of viable counts( $\mathrm{CFU} / \mathrm{g}$ ) of the broiler poultry feeds and different ingredients were illustrated in (Table 4). The mean values of the $\mathrm{CFU} / \mathrm{gm}$. at $37^{\circ} \mathrm{C}$ ranged from $(1.80 \pm 0.27) 10^{2}$ to $(6.48$ $\pm 2.19) 10^{4}$. The results showed that the lowest mean colony count was in the bone meal $(1.80 \pm 0.27) 10^{2} / \mathrm{gm}$. while the soya bean meal showed the highest mean colony count (6.48 $\pm 2.19) 10^{4} / \mathrm{gm}$. Results were given in (Table 4) revealed that all examined samples proved to be highly contaminated with coliforms. The minimum mean value of the total coliforms counts/g was ( $2.26 \pm 0.31) 10$, in case of broiler gelutonine, while the maximum mean count was $(\mathbf{7 . 3 1} \pm 2.45) 10^{3}$, in case of broiler rations. The obtained results were more or less in agreement with that recorded by Cox, et. al. (1983) who found that the broiler rations contained high total coliforms counts than bone and meat meals. It is clear evident from the results recorded in (Table 4) that, E. coli could be detected in the commercial final broiler rations and most of the feed ingredients. The mean count/g varied from zero in case of fish meal, meat meal, bone meal and broiler concentrates to $(2.82 \pm 1.38) 10^{2}$ in broiler rations. On the other hand, (Table 4) showed that the mean values for Enterococcus count $/ 100 \mathrm{~g}$ ranged from zero to 27.63 \pm 3.76 . The maximum Enterococcus count was recorded in the corn meal (27.63 \pm 3.76$)$. Absence of E.coli and Faecal streptococci from broiler concentrates my be attributed either to the heat treatment during manufacturing or du to the products were not subjected to the faecal contamination. The distribution of Cl.perfringens in the examined samples was shown in (Table 4). The mean values of Cl.perfringens were ranged from zero to $(6.41 \pm 2.57) 10^{2} / g$. However, corn meal, soya bean meal bone meal, methionine and lysine were free from Cl.perfringens contamination.

Data presented in (Tables $5 a$ \& $5 b$ and 6) proved that the poultry feed rations and their ingredients were highly contaminated with many pathogenic and potentially pathogenic organisms.It was easily noticed that Staphylococcus spp. represented one of the 
most important contaminants of the broiler rations and their ingredients with a total incidence percentage of $\mathbf{1 4 . 1 2} \%$ and over all frequency percentage of $36 \%$. Also E.coli was isolated with an over all frequency $10 \%$ and total incidence of $3.92 \%$ (Table 6). From data illustrated in (Tables 5a \& 5b), it could be concluded that the broiler rations; soya bean meal and corn meal were the most contaminated samples with E.coli. Its also evident from the obtained results that Pseudomonas aeroginosa could be isolated with a total incidence of $5.88 \%$ and over all frequency percentage of $15 \%$ from the all of final rations, concentrates and feed ingredients (Table 6). Salmonella species could not be detected from all examined samples. On the other hand, Cl.perfringens could be isolated with over all frequencies of $13 \%$ and a total incidence of $5.10 \%$ from final rations, concentrates and feed ingredients, (Table 6). The high frequency percentage of Cl.perfringens in the feed concentrates may be due to to insufficient heat treatment and resistance of their spores during processing or due to the post manufacturing contamination. Other organisms of minor health significance were also recovered with variable frequency percentages as Alcaligenes faecalis; Enterobacter cloecae; Serratia.rubidae; Proteus morganii; Proteus. vulgaris, Providancia spp.; Citrobacter freundii; Citrobacter diversus and Arizona spp. (Tables $5 a$ \& $5 b$ and 6$)$.

The present data concluded that the associated microbiological problems of broiler poultry feeds and their ingredients were more widespread than was commonly believed. Moreover, the products and techniques to correct these problems are underutilized. It is suggested that, there is a great room for improvement the control of microbiological quality in all practical aspects of poultry feed manufacturing and storage. In general, the all of, a good manufacturing practice of poultry feeds and their ingredients; perfect heat treatment ; correct handling and storage of raw materials and keeping the moisture level very low in the final products are considered the main measures that must be used to minimize risks of poultry feeds and feed ingredients contamination and to maintain the progressive improvement and development of poultry industry in our countries.

\section{REFERENCES :}

Abaraca, M.L.; Bragulat, M.R.; Castella, G. and Cabanes, F.J. (1994): Mycoflora and aflatoxin-producing strains in animal mixed feeds. J. Food production 57 (3) : 256 - 258.

Abdel-Fattah, A.M (1994): Public health hazard of myco-contamination of some cereal to human and animal health. Assiut Vet. Med. J. 31, No.61: 209-215.

Abdel-Kader, M.A.; Moubasher, A.H. and Abdel-Hafzy,S.I. (1979): Survey of mycoflora of barley grains in Egypt. Mycopathologia 68: 143-147.

Adams,A. (1987): Moulds and mycotoxins in animals feed material. Poult. Sci. 62: 3112-3113.

Aharonwitz,Y and Cohen, ,G.(1981): The microbiological products of pharmaceuticals. Sc. Amer. 245 (3) : 140-147.

Ahmed, M.M; Sotohy A.S; Ismail, A.A. and Ismail, M.A. (1995): Bacteriological evaluation of poultry feeds and feed ingredients in Assiut Governorate. Assiut Vet. Med. J. Vol. 34, No. 67. 
American Public Health Association (1985): Standard methods for the examination of water and wastewater. $16^{\text {Th }}$ Ed., Washington, D.C., U.S.A.

Baily,W.R. \& Scott, E.G. (1994): Diagnostic

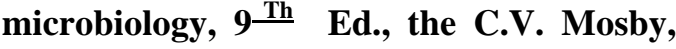
and Saint Louis.

Balachandran, C. and Ramarkrishnan, R. (1988): Influence of dietary aflatoxin on certain serum enzymes levels in broiler chickens. Mycopathologia, 101,65-67.

Bartove, I; Paster, N. and Lisker, N. (1982): The nutritional value of mouldy grains for broiler chicks. Poultry Sci., 61: 2247-2254.

Bartove, I. (1983): Effect of propionic acid and copper sulphite on the nutritional values of diets containing moldy corn . Poult. Sci. 50: 2195-2200

Bodine, AB; Mertens, DR. (1983): Biological effects of aflatoxins burn. Univ. Ext ST Res Bul 279: 46-50.

Bryden, W.C.; Cumming,RB. And Liody, AB. (1980): Avian Path., 9: 539-550.

Chang-Yen, I.; Bidasee, $K$. and Rampersad, G. (1992): Mycoflora and Mycotoxinproducing potential fungi from poultry feeds and feed ingredients in Trinidad. $J$. Sci., Food Agric. 60: 283-286.

Cox, N.A.; Bailey, J.S. and Thomson, J.E. (1983): Salmonella and other Enterobacteriaceae found in commercial poultry feed. Poultry science, 62: 2169-2175.

Cruickshank, R.; Duguid, J.P.; Marmion, B.P. and Swain, R.H. (1980): Medical microbiology, 12 Th Ed., vol., reprinted Churichill Livingestone \& Robert Stevenson Edinburgh, EH I, 3AF.

Das, A;Charrerjee, M. and Ray,A.(1979): Enzymes of some higher fungi. Mycologia 71:530-536.
Drupt, F.F.(1974): Calorimetric determination of serum albumin and globulin. Pharm. Biol., vol.9 : 77-79.

El-Gendy, S.M. (1966): Microbial assay of blue-veined cheese Roquiforte- type. Bull. Sci. Technol, (Univ. of Assiut, Egypt), 9: 367-384.

EI-Kady, I.; Abdel-Hafez, S. and ELMaraghy, S. (1982): Contribution to the fungal flora of cereal grains in Egypt. Mycopathologia 77: 103-109.

El-Maraghy, S.S.M. (1984): Natural occurrence of zearalenone and zearalernone producing fungi isolated from wheat grains, flour and bread in Egypt. Ph.D. Thesis Bot. Dept. Fac. Assiut University

Elmer, W.K.; Stephen, D.; Allen, M.D.; William, M. Janda; Schreckenberger, P.C. and Washington, C.W. (1994): Introduction to diagnostic microbiology. J.B. Lippincott company Philadelphia. Eupenicillium and Talaromyces. Academic press, London.

Fernandez, A; Maria Teresa Verder, M.; Gascon, J.; Ramos,J.; Gomez, D.F.; Luco and Chavez, G. (1994): Variations of clinical biochemical parameters of laying hens and broiler chickens fed aflatoxincontaining feed. Avian pathology 23: 37-47.

Gathumbi.J.K., Bebora, L.G.; Muchiri, D.J.; Ngatia, T.A. (1996): Mycological examination of poultry feed used in Nairoby, Kenya. Bulletin of Africa (1996) 44 (1)1922.

Giambrone, J.; Diener, U.L.; Avis, N.D.; Panangala, V.S. and Hoerr, F.J. (1985): Poultry Sci. 64: 1678-1684.

Hegazy, SH; Azzam, AH.,Gobal,MA (1991): Interaction of naturally occurring aflatoxins in poultry feed and 
immunization against fowl cholera. Poultry Sci. 70: 2425-2428

Hussain,M.; Wilson, T. and Summerfelt, RC (1993): Effect of aflatoxin-contami-nated feed on morbidity and residues in Walleye fish. Vet. Human Toxicol 35: (5).

Malkinson,M; Shlosberg,A; Egyed,M.N.; Avidar,Y.; Perl,S.; Weisman,Y.; Nobel,T.and Bogin,E. (1982): Hepatic cirrhosis suggesting aflatoxicosis in a flock of geese. Veterinary Record,110,101-103.

Niemice, J.; Schol, T.and Yssek, S (1989): The response of broiler chicken to feed containing Ochratoxin A. Annals of Warsaw Agricultural University SGGW. Ar, Animal Science No.24, 37-40

Ogundero, V.W. (1987): Toxigenic fungi and the deterioration of Nigerian poultry feeds. Mycopathologia, 19:75-83.

Okoye, J.O.A. and Okeke, C.N. (1986): Pathogenicity of isolate of Aspergillus flavus in chickens. Avian pathology, 15: 259-270.

Pier, A.C. (1992): Major biological consequence of aflatoxicosis in animal production. J. Animal Sci. 70: 3964-3967..

Prabaharan,S.; Titus George, V. and Balasubramaniam, G.A. (1999): Influence of dietary aflatoxin and coccidiosis on growth rate in broiler chicken Indian Vet. J. September, , 76: 827-828.

Quinn ,P.J.; Carter, M. E. ; Markey , B. K. and Carter, G. R. (1994) : Clinical Veterinary Microbiology Virginia Tech., Blocks Burg , U. S.A.

Reddy, DN., Rao, P.V.; Reedy, V.R. and Yadagiri, B.(1984): Indian J. Anim. Sci., 54: 68-73.

Robert, W.T. and Mora, E.C. (1978): Toxicity of penicillium citrium AUA-532 contaminated corn and citrinin in broiler chicks. Poultry Sci. 57 (5): 1221-1226.

Ruff, M.D. and Wyatt, R.D. (1978): Avian, Dis,. 22: 471.

Sendecor, G.W. and Cochran,W.G. (1980): Statistical methods. Iowa State Univ. Press. Ames, Iowa, U.S .A .

Singh, J. and Malhotra, F.C. (1978): Experimental studies of Aspergillosis in chicks Haryana Veterinarian, 17: 23-28.

Tabib, Z.; Jones, F.T. and Hamilton, P.B. (1981): Microbiological quality of poultry feed and ingredients. Poultry Science, 60: 1392-1397.

Topley,W.W.C. and Wilson ,G. S. (1990) : Principles of bacteriology, Virology and Immunity. 8 th Edition Systematic Bacteriology.

Udhaya Kumar, m., Padmavathi, P. and Ramesh, A.J. (1995): Indian Vet., 72; 1141.

Uliman, U. and Blasin,C. (1974): A simple medium for the detection of different lipolytic activity of microorganisms. Zentralb. Bakteriol.Hyg. A.ABT. 229: 264267.

Weichselbaum, P.E.(1946): An accurate and rapid method for detection of protein in small amount of blood serum and plasma. A.J. Clinic Path. 16: 40-42.

Youssef, N.; Refai, M.; EL-Molla, A. and ELGamma, H. (1985): Mycotic flora and aflatoxin contamination of grains. $J$. Egypt. Vet. Med. Ass. 45 (4): 69-81. 


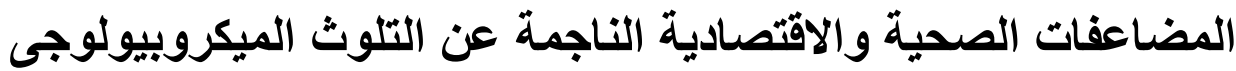

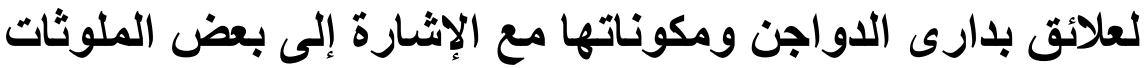
الفطرية المفرزة للسموم الأنمارة

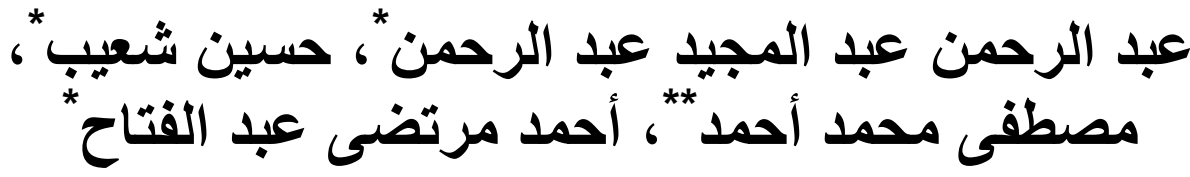

*معه بحوث صحة الحيوان- الدقى- الجيزة ، ** قسم الصحةـ كلية الطب البيطرى- جامعة أسيوط

أجريت الاراسـة على . . 1 عينـة من علائق بدارى الدواجن ومكوناتها تم تجميعها من

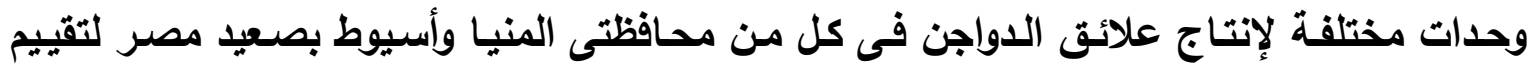
محتواها من التلوث الميكروبيولوجى ، وقد أظهرت النتائج عن وجود أعداد من من الفطريات ولفيات والخمائر

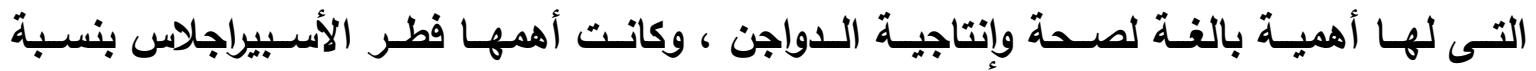

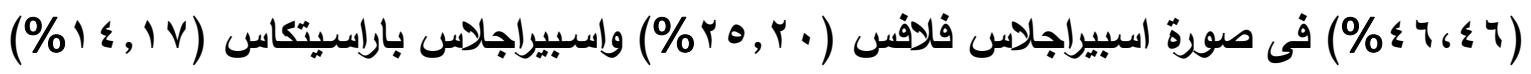

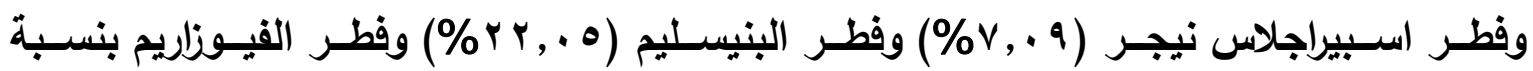

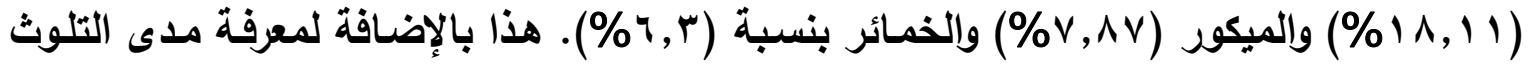
الميكرويسى لمثل هذه العلائق ومكوناتها فقد تم إجراء العد الكلى العيوى لإجمالى الميكرويـات

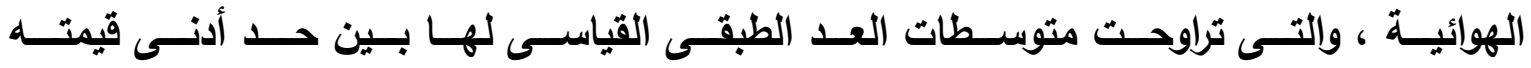

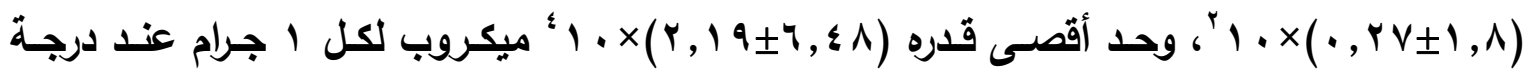

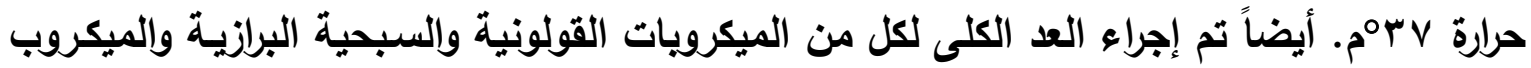

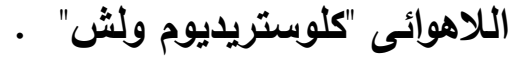

كما أظهرت النتائج عن وجود تباين واضـح بين متوسطات العد الكلى لهذه الميكرويات.

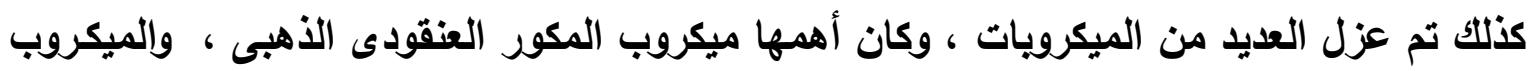

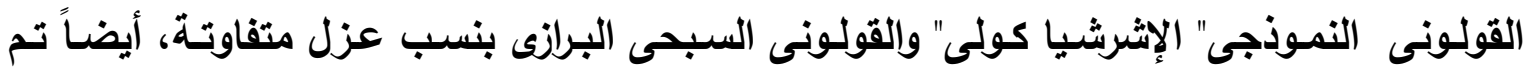
اختبار عدد من الفطريات المعزولة والهامـة، والتـى قد تم عزلها من العلائق المختبرة ومكوناتها

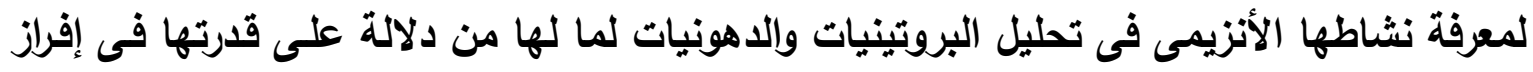

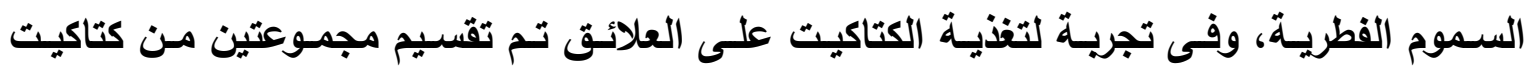


التسمين كل واحدة منهما تحتوى على · r كتكوت عمر يوم واحد ، وتم تغذيتهما لمدة 7 أسـابيع متصلة على هذه العلائق التى عزلت منها العترات الفطرية والتى أظهرت نشـاط إنزيمى للمجموعة الأولـى بينمـا تـم تغذيـه المجموعـة الثانية على نفس العلائق ، ولكن بعد إضـافة مضـاد السـموم الفطرية للعليقة بنسبه ا جرام لكل كجم عليقة. وقد تم إجراء اختبار وظائف الكبد وتقدير نسب البروتين والكالسيوم والفسفور فى مصل الام.

وقد أسفرت النتائج عن وجود اختلاف جوهرى فى هذه النسب للمجموعة الأولى التى لـ تضاف إليها مضاد السموم ، وكذلك لوحظ نقص واضح فى متوسط أوزانها بالإضافة لكفاءة تحويل غذائى أقل عن مجموعة الكتاكيت الثانية. وقد تم مناقشة أهم الإجراءات الوقائية والصحية لمداولة علائق الدواجن ومكوناتها أمسلاً فى الحصول على منتج ذات جوده عاليـة يخلو من المسببات الميكرويية والفطرية وعلى الأخص المفرزة منها للسموم الفطرية حفاظاً على الثروة الداجنة وصحة •الإنسان 